\title{
Comparative Effectiveness of Angsana Latex (Pterocarpus indiscus) and Chlorhexidine $0.2 \%$ Against Growth of Streptococcus mutans
}

\author{
Wimmy Safaati Utsani ${ }^{1}$, Mahmud Kholifa ${ }^{2 *}$ \\ ${ }^{1}$ Faculty of Dentistry, Muhammadiyah University of Surakarta, Surakarta, Indonesia \\ ${ }^{2}$ Oral Biology Department, Faculty of Dentistry, Muhammadiyah University of Surakarta, \\ Surakarta, Indonesia \\ *Email: mk111@ums.ac.id
}

\begin{abstract}
The aim of this research was to investigate the comparative effectiveness of angsana latex $(P$. indiscus $)$ and chlorhexidine $0.2 \%$ against growth of $S$. mutans. This research was a laboratory experiment (true experimental), with a post-test only completely randomized design, consisting of four treatments: angsana latex $40 \%(\mathrm{w} / \mathrm{v})$, angsana latex $80 \%(\mathrm{w} / \mathrm{v})$ positive control (chlorhexidine $0.2 \%$ ), and negative control (distilled water). Each treatment was replicated six times. The bactericidal effect of the inhibition zone that formed on Muller-Hinton media was rated. Result: One-way analysis of variance showed that the inhibition zones were significantly different; the angsana latex $80 \%(\mathrm{w} / \mathrm{v})$ had a larger mean inhibiting zone than that of chlorhexidine $0.2 \%$ against $S$. mutans. These results indicate that angsana latex $80 \%(\mathrm{w} / \mathrm{v})$ had a greater bactericidal effect than that of chlorhexidine $0.2 \%$ against $S$. mutans.
\end{abstract}

Keywords: comparative effectiveness, angsana latex, chlorhexidine $0.2 \%$, Streptococcus mutans

\section{Introduction}

Dental caries is the decay process that starts from enamel and continues into dentin. Dental caries is a disease associated with many factors. Data from the Ministry of Health of the Republic Indonesia in 2010 show that the prevalence of dental caries in Indonesia is $60-80 \%$ of the population and ranks sixth as a disease most suffered [1]. One of the main causes of dental caries is the Streptococcus mutansproducing enzyme glucosyltransferase [2.3]. There are many ways to prevent dental caries, including antiseptic mouthwash, which decreases the number of colonies of pathogenic bacteria in the oral cavity and reduces the occurrence of plaque, and dental caries [4] One of the recommended mouthwash antibacterial agents is chlorhexidine gluconate $0.2 \%$ as a standard in dentistry, but chlorhexidine has side effects such as staining of teeth and reduced taste when used over the long term. Thus, alternative raw materials are needed to prepare an economical and efficacious mouthwash with minimal side effects. These alternative ingredients include herbs [5]. A medicinal plant that is widely used as an herbal medicine is the latex of the angsana tree (Pterocarpus indiscus). The antimicrobial activity of angsana latex supports the use of traditional medicines associated with bacterial conditions in humans and can be used to fight multi-resistant microbes [6]. However, it is un- 
known whether the latex from the angsana tree has a bactericidal effect equivalent to chlorhexidine $0.2 \%$ for inhibiting the growth of $S$. mutans, so a comparative study on the bactericidal effect of angsana latex and chlorhexidine $0.2 \%$ against $S$. mutans is needed.

This study was aimed at demonstrating that the bactericidal effect of angsana latex is equivalent to that of chlorhexidine $0.2 \%$ for inhibiting the growth of $\mathrm{S}$. mutans. The specific objective of this study was to measure the inhibition zone of $40 \%$ and $80 \%(\mathrm{w} / \mathrm{v})$ angsana latex concentrations compared to that of chlorhexidine $0.2 \%$ against growth of $\mathrm{S}$. mutans. The results of this research are expected to provide scientific evidence for the bactericidal effect of $40 \%$ or $80 \%$ (w/v) angsana latex equivalent to chlorhexidine $0.2 \%$ for inhibiting the growth of $S$. mutans. Angsana latex will be useful in further basic further research to produce an oral antiseptic containing angsana latex.

Caries is a disease of the enamel, dentin, and cementum caused by the activity of bacteria on fermented carbohydrate in the oral cavity. Caries is a pathological process of tooth demineralization due to acid production in the mouth. A sign of a caries is demineralization of dental hard tissue followed by damage to the organic material resulting in bacterial invasion and death of the pulp. Dental caries are characterized by tissue damage, starting from the tooth surface (pits, fissures, and interproximal areas) and extending to the pulp. The main microorganisms in the mouth that are associated with caries are S. mutans and Lactobacillus. S. mutans is a plaque dominant bacterium. These bacteria are cariogenic as they immediately produce acids from carbohydrates that can be fermented. The bacteria thrive in acidic conditions and attach to the tooth surface because of their ability to make external polysaccharides stick to teeth. These polysaccharides consist of glucose polymers, which cause a dental plaque matrix with a consistency like gelatin that consequently helps the bacteria stick to teeth [7].

$S$. mutans is a Gram-positive bacterium that includes the varidians group. $S$. mutans is a facultative anaerobic, acidogenic bacterium that produces acid and a sticky polysaccharide called dextran. Thus, $S$. mutans supports other bacteria that attach to the tooth enamel and supports growth of other acidoduric bacteria, resulting in solubilized enamel [8]. S. mutans is a cariogenic bacterium because it produces an acidic form of carbohydrates, which can be fermented. Extracellular polysaccharides consist of a matrix polymer of glucose that causes plaque and has a gelatin-like consistency. Plaque becomes thicker over time, and the salivary function can be inhibited because of bacterial activity. The ability of $S$. mutans to exploit some extra and intracellular storage compounds has ecological benefits and increases the amount of acid in the oral cavity. These acids cause environmental resistance of bacteria that flourish in the plaque matrix environment with a low $\mathrm{pH}$ within demineralized enamel; thus, beginning the process of dental caries [9].

Pterocarpus indiscus is a deciduous tree with a height of $30-40 \mathrm{~m}$ and a trunk diameter of more than $2 \mathrm{~m}$. The wood exudes a dark red latex called "kino" or "dragon's blood." Compound leaves with 5-11 leaflets are hairy. Flowers have a length of $6-13 \mathrm{~cm}$. The flowers are bisexual, yellow, bright, and fragrant. The angsana plant has a large number of uses. Most communities process the tree for food (bark), latex (resin), and the leaves. In some areas, the shredded bark is 
boiled and the liquid is taken orally to treat dysentery and diarrhea. Angsana latex has health benefits too, such as antidiarrheal antifever, and antiaging as well as the ability to accelerate wound healing of burns. Phenols, flavonoids, saponins, triterpenoids, and tannins are abundant in this plant [10]. Flavonoids are antibacterial as they inhibit synthesis of nucleic acids and block bacterial motility. Flavonoids works by interfering with the binding of hydrogen in nucleic acids so that DNA-RNA synthesis is inhibited. In addition, flavonoids prevent growth of bacteria by disrupting the stability of the cell membrane and the energy metabolism of the bacteria, resulting in cell death. The reductase enzyme used in the bacterial electron transfer process leads to impaired bacterial growth [11].

Chlorhexidine is typically used to remove contaminant bacteria. Chlorhexidine is also effective for reducing growth of $S$. mutans found on the exposed root surfaces in caries. Therefore, the antibacterial chlorhexidine is also recommended as a cavity disinfectant before placing a restoration [12]. Chlorhexidine has cytotoxic effects on odontoblast cells lining the pulp. Odontoblasts are specialized cells that have an important role healing pulp and forming the mineralized tissue barrier. The presence of chemical substances can interfere with odontoblasts by damaging the pulpodentinal layer directly and inducing apoptosis or death of these cells due to cytotoxic effects [13].

\section{Materials and Method}

This research was a pure laboratory experiment (true experimental) with a posttest only randomized design consisting of four treatments: Angsana latex $40 \%$ $(\mathrm{w} / \mathrm{v})$, angsana latex $80 \%(\mathrm{w} / \mathrm{v})$, positive control (chlorhexidine $0.2 \%$ ), and negative control (distilled water). Each treatment was replicated six times. The number of repetitions for each treatment group were obtained from a calculation using the Federer formula.

\subsection{Material and Equipment}

The materials used in this research were angsana latex $40 \%(\mathrm{w} / \mathrm{v})$, angsana latex $80 \%$ (w/v), chlorhexidine $0.2 \%$, distilled water, S. mutans, Muller-Hinton agar, and brain heart infusion media (BHI). The equipment used in this study included an analytical balance, Petri dishes, Bunsen burner, sterile cotton stick, funnel, glass beakers, small test tubes, rack test tubes, pipettes, micropipettes, autoclave, incubator, and stem glass stirrer.

\subsection{Dilution of Angsana Latex}

Angsana latex was diluted with sterile distilled water to concentrations of $40 \%$ and $80 \%$. The $40 \%$ (w/v) concentration was created by adding $2 \mathrm{~g}$ angsana latex to a tube and bringing the volume up to $5 \mathrm{ml}$ with distilled water. The $80 \%(\mathrm{w} / \mathrm{v})$ concentration was prepared by adding $4 \mathrm{~g}$ of angsana latex and bringing the volume up to $5 \mathrm{ml}$ with distilled water.

\subsection{Sterilization}

All equipment was washed, dried, and sterilized in autoclave at $121^{\circ} \mathrm{C}$ for $15 \mathrm{~min}$. 


\subsection{Preparation of Bacteria}

$S$. mutans was scraped into blood agar media and placed in a $37^{\circ} \mathrm{C}$ incubator for $24 \mathrm{~h}$. After the incubation, $S$. mutans was detected as small round 1-2 $\mu \mathrm{m}$ diameter colonies. The bacterial colonies were grown for $24 \mathrm{~h}$ suspended in $0.5 \mathrm{ml} \mathrm{BHI}$ medium and then incubated for $5-8 \mathrm{~h}$ at $37^{\circ} \mathrm{C}$. Sterile distilled water was added to the bacterial suspension so turbidity was $3 \times 108 \mathrm{cfu} / \mathrm{ml}$ according to the standard Mc Farland I concentration of bacteria.

\subsection{Antibacterial Testing}

The bactericidal effects of the $40 \%$ and $80 \%$ (w/v) angsana latex were tested with $3 \times 108 \mathrm{cfu} / \mathrm{ml}$ on a sterile cotton swab, which was smeared on Muller-Hinton agar medium. Then prepare 24 pieces spitting, which each divided into four groups for angsana latex $40 \% \mathrm{w} / \mathrm{v}$, angsana latex $80 \% \mathrm{w} / \mathrm{v}$, chlorhexidine $0.2 \%$, and distilled water. Six discs were added to each Petri dish containing angsana latex $40 \%$ (w/v), angsana latex $80 \%$ (w/v), chlorhexidine $0.2 \%$ and as much as one drop of distilled water followed by a $37^{\circ} \mathrm{C}$ step incubation for $24 \mathrm{~h}$. The bactericidal effect was assessed by measuring the diameter of inhibition zones around the pitting using calipers.

\section{Results}

The inhibition zone measurement results from each treatment are shown in Fig 2.
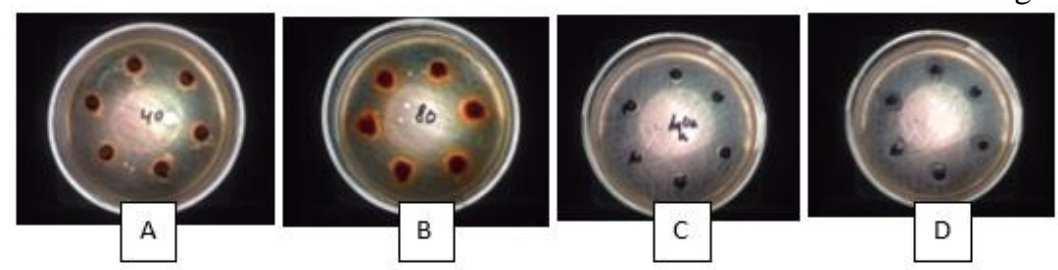

Fig 1. Inhibition zones of $40 \%$ angsana latex (A) $80 \%$ angsana latex (B), distilled water (C), and $0.2 \%$ chlorhexidine (D) against Streptococcus mutans

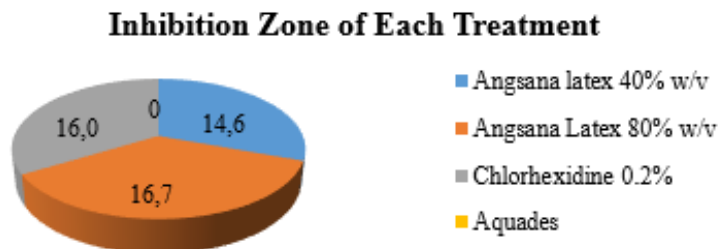

Fig 2. Inhibition zones ( $\mathrm{mm})$ of each treatment

Fig 2 shows the variations in the inhibition zones formed by each treatment. The measurement results shown in Fig2 are the average diameters of the inhibition zones after a $24-\mathrm{h}$ incubation. The $40 \%$ angsana latex concentration was able to inhibit the growth of $S$. mutans colonies. However, the $80 \%$ concentration was used as the benchmark to compare with the positive and negative controls because it produced the largest inhibition zone. 
The average diameter of the inhibition zone created by $80 \%(\mathrm{w} / \mathrm{v})$ angsana latex was the largest compared with chlorhexidine $0.2 \%$ and distilled water on bacterial growth of Streptococcus mutans with an average of $16.667 \mathrm{~mm}$. Table 2 shows the significant differences between groups.

The inhibition zone diameter was significant $(\mathrm{p}<0.000)$ among all groups after the $24 \mathrm{~h}$ incubation period (Table 3 ).

\section{Discussion}

S. mutans has the ability to support sticking of other bacteria to tooth enamel, which causes dental caries.15 Cavity cleanser is a material disinfectant that removes the smear layer after the tooth is prepared. The most common cavity cleanser is chlorhexidine $0.2 \%$. Chlorhexidine has a wide spectrum of antibacterial activity against Gram-positive bacteria, such as $S$. mutans [16]

Our results show that the angsana latex and chlorhexidine $0.2 \%$ inhibited the growth of $S$. mutans. Angsana latex $80 \%$ (w/v) was most effective when compared with chlorhexidine $0.2 \%$ for inhibiting the growth of $S$. mutans. Angsana latex $80 \%$ (w/v), which was derived from herbal ingredients, can be used as an alternative cavity cleanser because it was able to maximally inhibit bacteria. The average inhibition zone for angsana latex $80 \%(\mathrm{w} / \mathrm{v})$ was $16.667 \mathrm{~mm}$ whereas that of chlorhexidine $0.2 \%$ was $16.083 \mathrm{~mm}$. Angsana latex contains antibacterial flavonoids. Flavonoids damage permeability of the bacterial cell wall, microsomes, and lysosomes resulting in an interaction between the flavonoid and the bacterial DNA.

\section{Conclusions}

We conclude that angsana latex $80 \%(\mathrm{w} / \mathrm{v})$ has a bactericidal effect greater than that of chlorhexidine $0.2 \%$ against growth of $S$. mutans. Further research is needed to determine the safe dose of angsana latex $80 \%(\mathrm{w} / \mathrm{v})$ that is equivalent to chlorhexidine $0.2 \%$ for inhibiting the growth of $\mathrm{S}$. mutans as a solution cavity cleanser in the field of dentistry.

\section{Acknowledgement}

We thank the Faculty of Dentistry Muhammadiyah University of Surakarta as funders of our research.

\section{References}

1. 2017. Available from: URL: www.tempointeractive.com $/ \mathrm{hg} /$ nasional/

2. Imaculata R, Tedjosasongko U, Cornelia S. Giving sesame oil (Sesamum indicum, L) to Streptococcus mutans (in vitro). Indonesian Pediatric Dent J. 2010; 2 (3): 2.

3. Dharsono VA, Mooduto L, Prasetyo EP. Differences in the number of colonies Streptococcus mutans in the saliva of patients men and women with a high caries. Conser Dent J. $2013 ; 3$ (1): 2.

4. Sumono A, Wulan A. The ability of the water decoction of leaves (Eugenia polyantha W) in reducing the number of bacterial colonies Streptococcus sp. Indonesian Pharmaceut Magazine. 2009; 20 (3): 112-113. 
5. Victor BC, Indrawati R, Sidarningsih. Differences inhibition of mouthwash green tea extract (Camellia sinensis) and methyl salicylate to growth bacteria of the oral cavity. Oral Biol Dent J. 2011; 3 (2): 1.

6. Sharif S. Screening of medicinal plant on antimicrobial caused caries and plaque forming activity. Indonesia J Nature Mat. 2007; 6 (2): 66- 70.

7. Anggraini LD, Pearl TCS. Index of caries and periodontal tissue condition on elementary school children aged 6-12 years. Proceedings PIN IDGAI V. 2011; 355-368.

8. Oktanauli P, Frances N, Lidiawati. The antimicrobial effects of green tea polyphenols to Streptococcus Mutans. JITEKGI. 2011; 8 (2): 9-23.

9. Gani B, Zainatul H, Santi C, Subhaini J, Abdillah IN, Endang W, et al. The degree of reactivity epileptic immunoglobulin (Igy) against a surface protein various serotypes Streptococcus Mutans using Elisa. DENTIKA. 2009; 14 (2): 153-7.

10. Junanto. Angsana extract antimicrobial activity (Pterocarpus indicus) to Bacillus Subtilis and Klebsiella Pneumonia. Biotechnology. 2008; 5 (2): 63-69.

11. Chismirina S, Poppy A, Nopi YF. The effect of fruit extract Jamblang against growth of Streptococcus mutans as a major cause of caries. DENTIKA. 2011; 16 (2): 144-8.

12. Kapdan A, Öztaş N, Sümer Z. Comparing the antibacterial activity of gaseous ozone and chlorhexidine solution on a tooth cavity model. J Clin Experiment Dent. 2013;5(3):e133.

13. Lessa FC, Aranha AM, Nogueira I, Giro EM, Hebling J, Costa CA. Toxicity of chlorhexidine on odontoblast-like cells. J Appl Oral Sci. 2010;18(1):50-8.

14. Dahlan MS. Statistics for medicine and health. Jakarta: Salemba Medika. 2012; p. 89.

15. Oktanauli P, Frances N, Lidiawati. The antimicrobial effects of green tea polyphenols to Streptococcus mutans. JITEKGI. 2011;8(2): 9-23.

16. Habeeb HM, AL-Mizraqchi AS, Ibraheem AF. Effect of ozonated water on adherent Mutans Streptococci (In vitro study). J Baghdad Col Dent. 2009;21(1):18-23. 